\title{
Possibilities to Apply the Urban Acupuncture Concept in Kaunas: Social Aspect
}

\author{
Aurelija Daugèlaitė, Indrè Gražulevičiūtè-Vileniškè, Mantas Landauskas \\ Kaunas University of Technology
}

\begin{abstract}
The concept of urban acupuncture, which has been gaining ground in recent decades, is based on the activation and revitalization of urban environments using small architectural or landscape architectural interventions in precise carefully selected locations of urban fabric. However, the rapid and unexpected design solutions of urban acupuncture, based on ecological design, nature dynamics, street art, material re-use, can cause different social and psychological reactions of urban population and these reactions may vary depending on cultural contexts. Consequently, in order to implement successful urban acupuncture projects in Lithuanian cities, it is very important to find out public opinion and priorities in the fields of public space management, aesthetics, and public art. The aim of the research was to analyze the opinion of Kaunas city residents regarding these issues. For this purpose, a sociological questionnaire survey was used. The questionnaire containing 20 questions was designed, with the aim to find out the trends of use of public spaces in the city, the attitudes of residents towards street art and other small-scale initiatives in public spaces implemented in the recent years, possibilities of creating landscape architecture based on ecological ideas in urban environment, the attitude of inhabitants towards community spaces and community space design in the city, etc. 100 residents of Kaunas participated in this online administered survey. The survey has demonstrated general positive attitude towards contemporary design trends of public spaces and public art; however, the surveyed population expressed preferences towards fully equipped public spaces offering possibilities for a wide range of activities.
\end{abstract}

Keywords: urban acupuncture, public space, social acceptability, public art, ecological landscape architecture

\section{Introduction}

Contemporary research is increasingly becoming interdisciplinary and transdisciplinary and knowledge exchange and transfer between various fields becomes common both in research and practice. The field of urban studies is not an exception; the interface between spatial and social sciences, environmental research and psychology are gaining ground. The disciplines or research areas, such as environmental psychology, environmental ethics, environmental sociology, psychogeography [1] are emerging and developing in this field as well. Urban acupuncture is one of those examples of knowledge transfer (between traditional Chinese practice and urbanism) that was elaborated in the last decades of the 20th century. The cities here are viewed as "biological systems, receptive to holistic wellness plans" [2]. This concept concentrates on ecological, social, and information flows in the city and targeted interventions, affecting these flows, resulting in revitalization of wider surrounding territory. The complexity and management challenges of contemporary cities urge to search for such unconventional ideas that could complement or even replace some conventional city planning and management practices. Urban acupuncture interventions are often characterized by unconventional, rapid, experimental solutions, some degree of incompleteness, emphasis on natural dynamics, involvement of social initiatives, low implementation costs. The urban acupuncture solutions can lead to diverse public perceptions ranging from very positive to total rejection, due to favored ecological landscape architectural solutions, based on the natural processes and aesthetics of natural areas, reuse of various materials and objects, and street art initiatives. Thus, this issue must be carefully considered while designing individual or systematic urban acupuncture interventions.

The aim of this research was to analyze the social-psychological preferences of the residents of the second largest city in Lithuania Kaunas towards the interventions in the city that can be considered as the analogues of urban acupuncture and their general attitudes towards urban acupuncture. The methods used in the research include the analysis of literature, the sociological survey of Kaunas residents, the analysis and discussion of the survey results.

\section{Literature review \\ The concept of urban acupuncture}

One of the pioneers of urban acupuncture is the Finish architect, urbanist, artist and researcher Casagrande with his work in Taipei Treasure Hill, which was traditionally sustainable although derelict neighborhood [3]. Currently a wide range of urban acupuncture research and practice examples can be found, starting from the general and practical book "Urban Acupuncture" by J. Lerner [4] to more 
specialized research of digital urban acupuncture by Iaconesi and Persico [5], where they analyze the networking phenomena and potential in the age of internet communication, rapid data transfer and social networks or even neural networks in urban acupuncture [6]. Generally speaking, the concept of urban acupuncture is a theory that seeks to solve social and environmental problems in the urban environment with rapid, minimal and very well targeted interventions. Here, using the analogy of the traditional Chinese practice of acupuncture, the city is compared to human body, the objects in the city buildings, public spaces and streets etc. are seen as organs called Zang-fu in Chinese medicine, and the movement and activity of people and other flows (ecological, informational) are comparted to the energy Chi, which runs through the body. The purpose of urban acupuncture is to regulate these energy flows in the body of the city so that it can function properly [7]. The urban acupuncture interventions can be both individual and systematic: "a method known as urban acupuncture on the one hand tests the local effects of every project, and on the other hand establishes a network of points or dots to act upon" [6]. The online project Network of Urban Acupuncture exists, where each example of urban acupuncture around the world can be registered and demonstrated. The network uses urban acupuncture typology including urban aquapuncture (water-based interventions), musical acupuncture, public space interventions and other types of acupunctures [8]. There is a call even for wider knowledge transfer to urbanism and landscape architecture to improve life quality and health in contemporary cities: "exploring concepts from eastern medicine such as acupuncture, aromatherapy (or horticulture therapy), directional alignment with the sun and the moon, nocturnal gardens, botanical soundscapes and energy balancing might be applied to exert a positive impact on mental health in modern cities" [2].

\section{Social and psychological aspects in urban acupuncture}

Urban acupuncture has strong emphasis on social aspect. Even the term "social acupuncture" [9] exists and the social networking is used for this purpose [10]. It is commonly agreed that social and psychological aspects are very important in developing successful lively public spaces. The discourse about urban health is primarily focused on green spaces and walkability [2]; however, contemporary research employing surveys, statistics, monitoring devices and other technology, demonstrates that social-psychological-spatial links in the city can be much more complex and subtle. For example, the research carried out in the large Northern Italian city Turin has demonstrated, that "good accessibility to public transport, as well as a dense urban structure (versus sprawl), could contribute to a reduced risk of depression, especially for women and elderly, by increasing opportunities to move around and enjoy an active social life" [11]. Another study in the area, that is called psychogeography, demonstrates that urban design can strongly influence the patterns of human behaviour and the levels of stress. The study showed that beyond the well-documented restorative effects of green-spaces, many aspects of the urban surroundings can strongly effect moods and attraction to particular areas of the city [1]. The Project for Public Spaces (PPS) is a non-profit organization that analyses more and less socially successful public spaces and had distinguished a system of criteria for their assessment. The system includes such sets of characteristics as access and linkages, comfort and image, uses and activities, and sociability and presents the array of observation and public space assessment questions including: "Are people using the space or is it empty?; Is it used by people of different ages?; How many different types of activities are occurring - people walking, eating, playing baseball, chess, relaxing, reading?; Are people in groups? Are they talking with one another?" etc. [12]. Thus, developing urban acupuncture interventions in public spaces, socialpsychological aspects must be carefully considered.

\section{Aesthetics and preferences of public spaces}

The aesthetics and preferences of public spaces is another issue strongly related with effective urban acupuncture. Contemporary urban acupuncture interventions involve both street art and the design solutions based natural dynamics. It can be stated that successful and sustainable urban acupuncture intervention should positively affect both social and environmental dynamics. In order to achieve this, it must be both environmentally beneficial and socially and psychologically acceptable. Numerous researchers contributed to the analysis of landscape preferences. However, studies by American landscape architect and researcher Nassauer [13; 14] indicate, that there might be differences in people's preferences towards landscape in natural and urban areas. According to her, people prefer what can be referred to as "the aesthetics of care" in their everyday environment. Thus she advocates integrating the signs of stewardship and care into ecologically valuable interventions in urban environment and achieving both environmental education and social preferences in this way. Hence, people will be more likely to protect those landscapes that they perceive as aesthetically appealing, than those they consider ugly or boring. Aesthetic experience can help associate the pleasant feelings created by the perceived environments with 
Sociodemographic characteristics of respondents.

\begin{tabular}{|c|c|c|c|c|c|}
\hline Age & Percent & Education & Percent & Residency & Percent \\
\hline $18-29$ & 60 & Higher & 64 & Old town & 2 \\
\hline $30-45$ & 34 & Unfinished higher & 4 & New town & 7 \\
\hline $46-59$ & 6 & College & 11 & Šančiai & 24 \\
\hline & & Unfinished secondary & 2 & Žaliakalnis & 21 \\
\hline & & Secondary & 18 & Vilijampolè & 2 \\
\hline & & Vocational & 1 & Petrašiūnai & 1 \\
\hline & & & & Residential block area & 27 \\
\hline & & & & Suburbs & 16 \\
\hline Total & 100 & Total & 100 & Total & 100 \\
\hline
\end{tabular}

ecologically valuable landscapes, whose visual expression can only partly reflect their ecological functions [15]. Nassauer [13] in her North American study identified the following "maintained" landscape features preferred by the society: moved lawns, flowering plants and trees, feeders for animals and birds, clear, visible design elements, trimmed shrubs, vegetation planted in lines, fences, architectural elements, lawn decorations, painted surfaces, planting around the foundation of buildings. This might be relevant to urban acupuncture as well; however, the social landscape preferences may differ from culture to culture and Northern American preferences cannot be transferred directly to Lithuanian context. In many Lithuanian cities there exists a clear whole of natural, cultural and urban values shaped by the terrain, water bodies and the course of history [16] and traditionally Lithuanian landscape and even contemporary cities had maintained numerous natural features. Thus it is necessary to analyse social-psychological preferences not only towards public art, which is often a subject of tastes and debates, but also to fragments of natural environment in the urban environment in the Lithuanian context.

\section{Research method and tools}

Kaunas is a green city (green areas occupy circa 30 percent of city's territory [17]) with emerging street art culture. Even an illustrated guide for the street art of Kaunas exists [18]. Art and nature coexists together in Kaunas. Take for example Kaunas Picture Gallery which is situated near the green slopes and develops street art and installation culture as well. It is necessary to note, that even if Kaunas is a green city form statistical point of view, the majority of its green areas are "untamed" and had maintained their natural or semi-natural character. This makes a Kaunas city an interesting object for the study of social preferences for ecological interventions and street art.

The selected survey method - written questionnaire. The general population of the survey is the adult population (from the age of 18) of Kaunas. In order to reach the targeted population more effectively, the survey was administered online and was available for respondents from the $4^{\text {th }}$ till the $24^{\text {th }}$ of April 2018. 100 respondents had completed the questionnaire. In order to reach the potential respondents, the social media networks and the nongovernmental organization Fluxus Labas working in the frame of the event Kaunas Capital of Culture 2022 were actively involved. This survey can be viewed as a pilot study, providing a framework for the further research on urban acupuncture in the context of Kaunas.

The questionnaire included 20 questions, the majority of which were closed and semi-open. The introductory part of the questionnaire provided four questions (Nr. 1, 2, 3, 4) concerning the socialdemographic characteristics and the place of residence of respondents. The following questions (Nr. 5, 6, 7, 10, 11) were formulated in order to find out the information about the leisure and recreation activities, habits and their locations including the visiting of places, that can be referred as the analogues of urban acupuncture: the Cabbage Field in historic district Šančiai, Courtyard Gallery and the street art zone in the city center etc. The questions $14,16,17,18,19$ were intended to elicit the potential involvement of communities in urban acupuncture interventions. At the end of the questionnaire the respondents were asked to remember and identify the socially catalyzing interventions in the urban fabric of Kaunas, that had attracted the users to previously abandoned spaces.

\section{Research results and discussion}

\section{Sociodemographic characteristics of respondents}

The majority of the respondents (60\%) who participated in the survey were 18-29 years old, $34 \%$ - 30-45 years old, 6\% - 46-59 years old. Older than 59 years old respondents did not participate in the survey. $71 \%$ of respondents were women and $29 \%$ - men. The majority of respondents had acquired higher education (64\%), unfinished higher education $(4 \%)$ or college education $(11 \%)$. The rest 21 percent of respondents had acquired unfinished secondary (2\%), secondary $(18 \%)$ or vocational education. Only few respondents live in former historic suburbs such as Vilijampolè (2\%) 
and Petrašiūnai (1\%). The rest $43 \%$ of respondents live in so-called sleeping districts and contemporary suburbs of Kaunas city.

\section{Trends of uses of public spaces}

One of the aims of this study was to find out the leisure habits and trends of using public spaces of the residents of Kaunas. The study showed that respondents usually spend their leisure time indoors: at home, in sports club, etc. (54 choices), at Kaunas historical center (54 choices), in the park or other city's green space (45 choices). Only $24 \%$ of the respondents spends leisure in their residential district (Fig. 1). Most of the respondents spend their free time in public spaces 2 times per week.

The preferable urban interventions of Kaunas city, implemented over the recent years, were selected and evaluated from the given list with photographs by the respondents. The presented interventions can be classified into community initiatives, artists' initiatives, interventions in city public spaces and public spaces of historic Vilijampole district that currently are not so popular. Respondents were asked to specify, which of these spaces they had ever visited.

The study showed that the least visited were small scale community's or artists' initiatives (Šančiai Cabbage Field - 26\%, Courtyard Gallery $27 \%$, street art zone $-48 \%$ ).

The most visited places were those, which were implemented in the public spaces of city's central part (embankment amphitheatre - 90\%, castle's amphitheatre $-64 \%$, Kaunas Picture Gallery with a courtyard and café 'Culture' - 67\%, former 'Fluxus Ministry’-64\%).

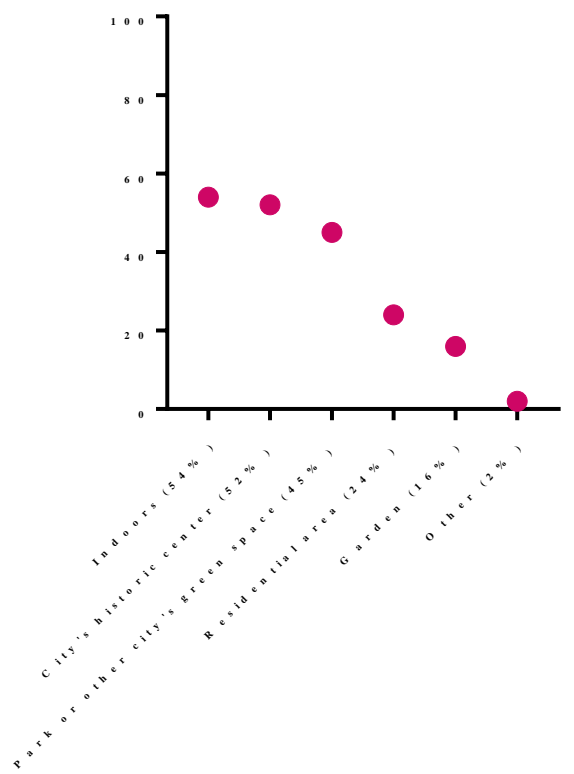

Fig. 1. Places of spending free time (percentage show how many people chose the answer).

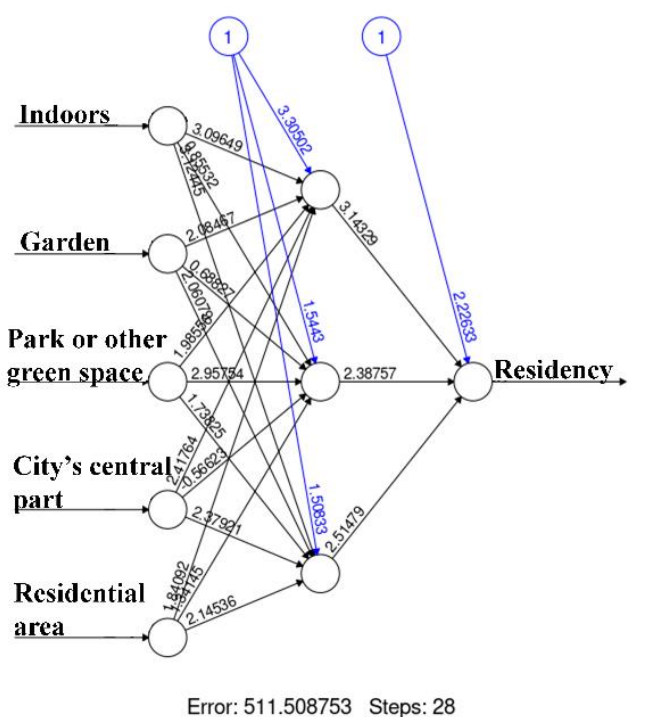

Fig. 2. Artificial neural network showing coherence of residency and leisure places.

Public spaces of quite unpopular historic district - Vilijampolè were also little visited (Neris riverside park - 40\%, Lampèdžiai beach $-49 \%$ )

It is presumed that interventions of a small scale are not well visited because they are not known very well and because it is necessary to visit them on purpose - they are away from the main pedestrian routes, or because they lack variety of activities.

The study tried to find coherence between the respondets' place of residence and the places of respondents' favorite leisure activities. Regression with factors did not show any significant results, therefore, artificial neural network was applied. Neural networks of 1-2 layers and 3-6 neurons were tested. The network has predicted with $27 \%$ accuracy. In general, the model showed that there was no significant multilayer and nonlinear coherences (Fig. 2).

\section{Perception of artistic-urban phenomena in the city}

As urban acupuncture interventions usually are based on kind of unexpected design solutions, the analysis of social-psychological aspects was important for this study. The study tried to find out the resident's attitudes towards small scale urban interventions, mostly of artistic nature. Therefore, respondents were asked to evaluate two sets of selected interventions in the scale from 1 (low evaluation) to 5 (high, positive evaluation): those that they have visited in Kaunas (Table 1) and those that might reveal different tolerance levels (provocative, promoting eco-awareness, entertaining activities and moderate arrangement interventions) (Table 2).

In case of the first set of interventions (those, which they had visited), respondents more 
Kaunas urban interventions (Set No.1.) ranked by the residents' evaluation in 1-5 point scale

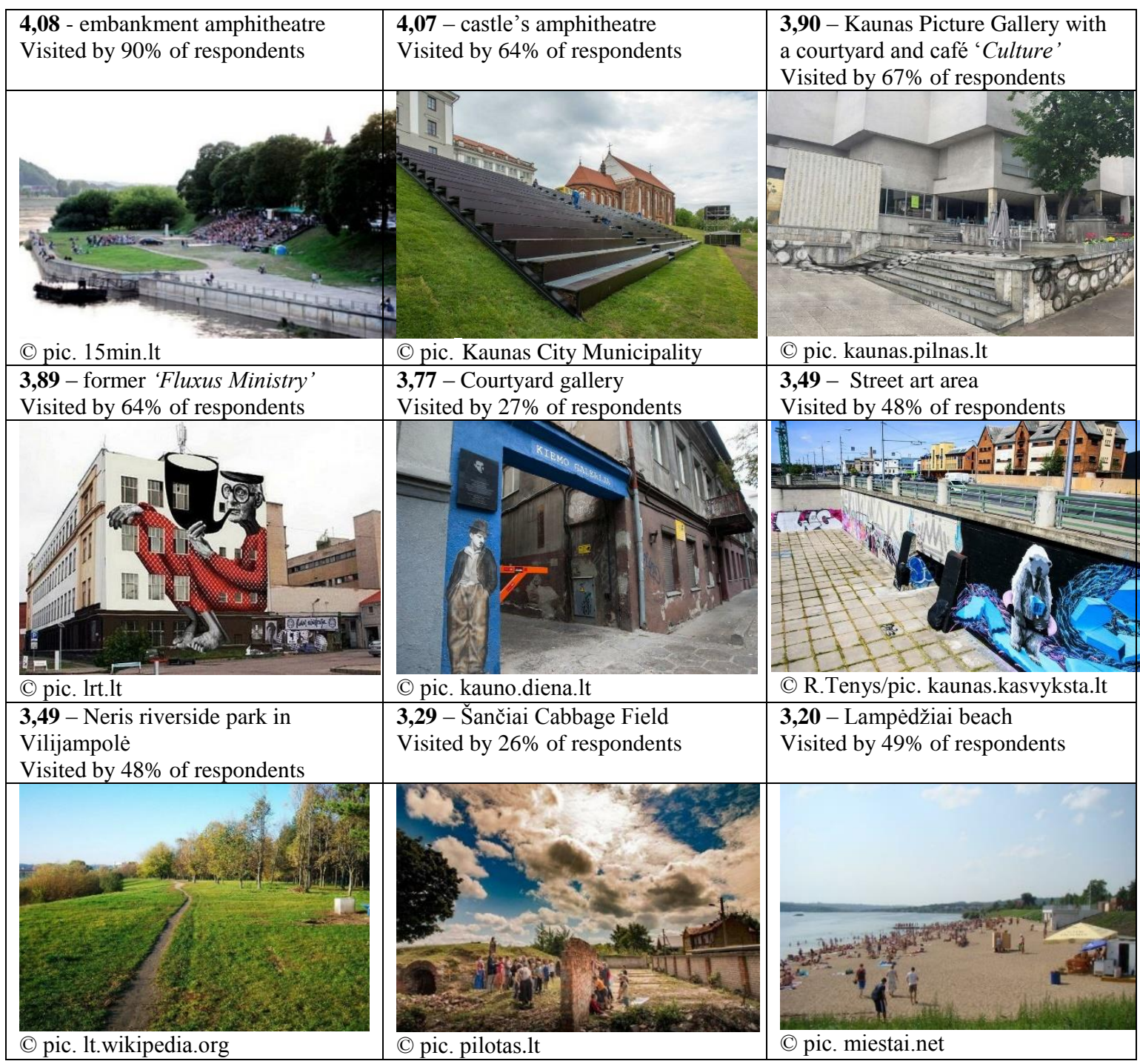

positively evaluated those places, which were located in the central part of the city, well maintained and fully equipped, as well as places with more activity opportunities (or activities around them) and places where events take place.

In case of the second set of interventions (those, which might reveal different tolerance level), respondents preferred the most so-called 'green' public space maintenance intervention (4,54 points). The majority of other interventions were evaluated as 'good' and the evaluations ranged between 4,43-3,53 points. The lowest scores (which were still relatively high $-3,16-3,04$ points) were given for those interventions, which people did not understand without additional explanation (e.g. monument for routine or inaccessible Mačiūnas square). In general, artistic interventions were evaluated positively - the average is 3,99 points.
The study tried to find out the coherence of age, education and evaluation of urban interventions. It was assumed that younger and more educated persons better evaluate urban interventions. Spearman's rank correlation was used for this purpose. The fig. 3 shows results of this correlation, where $p<0,05$ at the first three cases and $p=-0,01$ at the last case. The first three cases did not show significant coherence, however the last one showed very weak (however, still statistically insignificant) coherence between evaluation of urban interventions and education, which means that persons having lower education evaluate urban interventions more positively. The artificial neuron network was also applied in order to check the coherence; however, it did not show any significant results, which might be the result of data distribution or insufficient sample. 

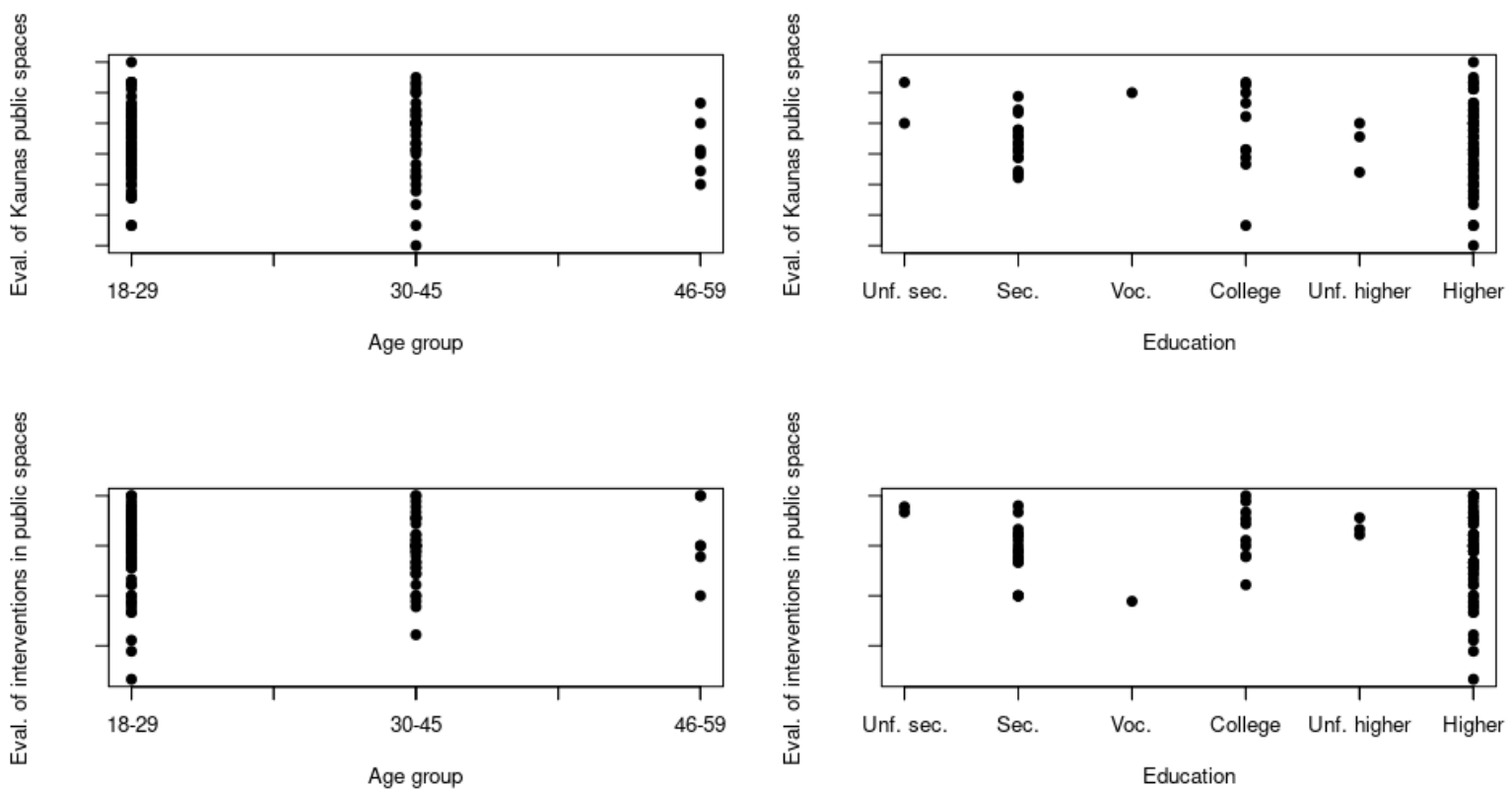

Fig. 3. Coherence of age, education and evaluation of urban interventions.

TABLE 3

Artistic-urban interventions (Set No.2.) ranked by residents' evaluation in 1-5 point scale.

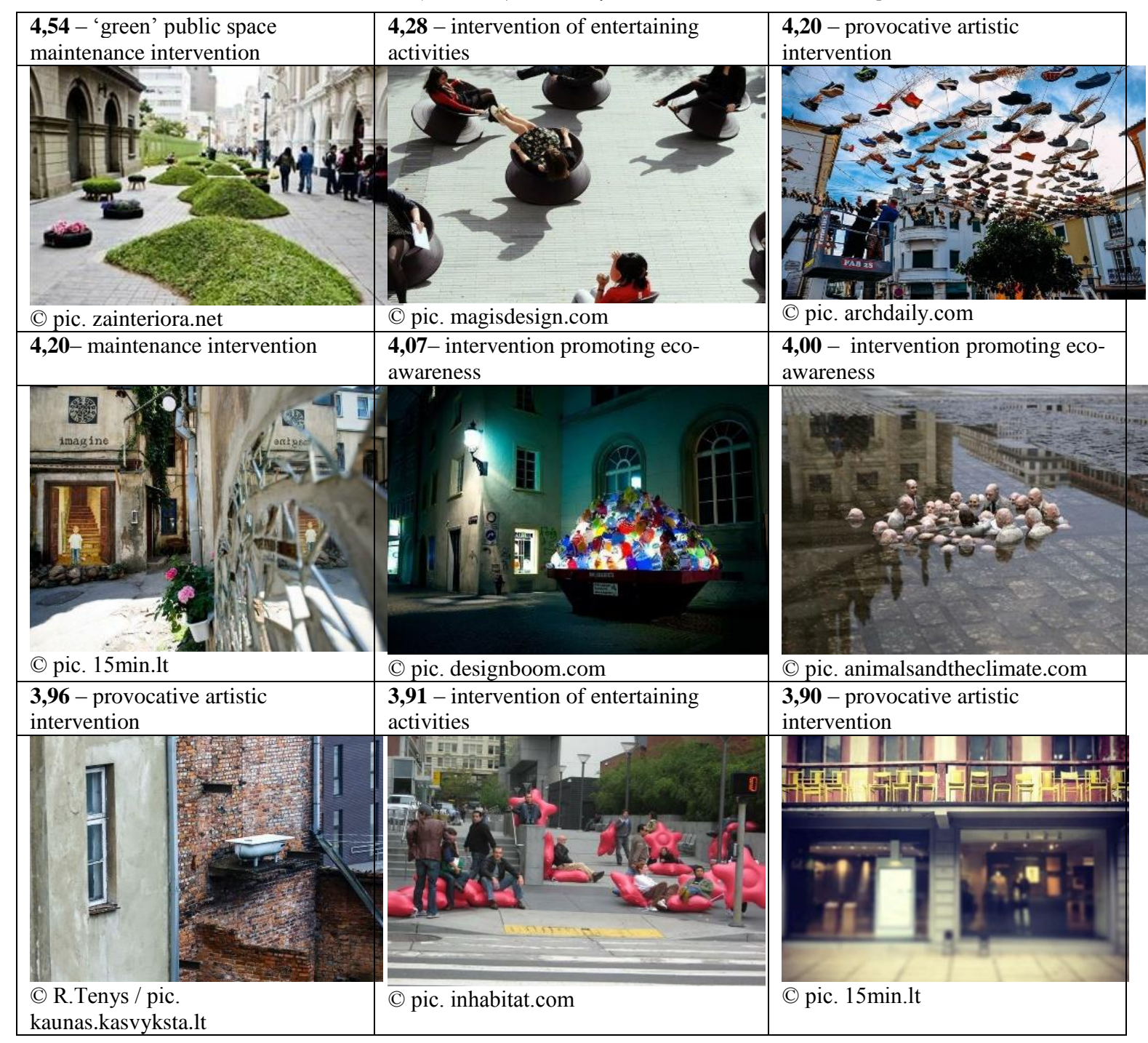




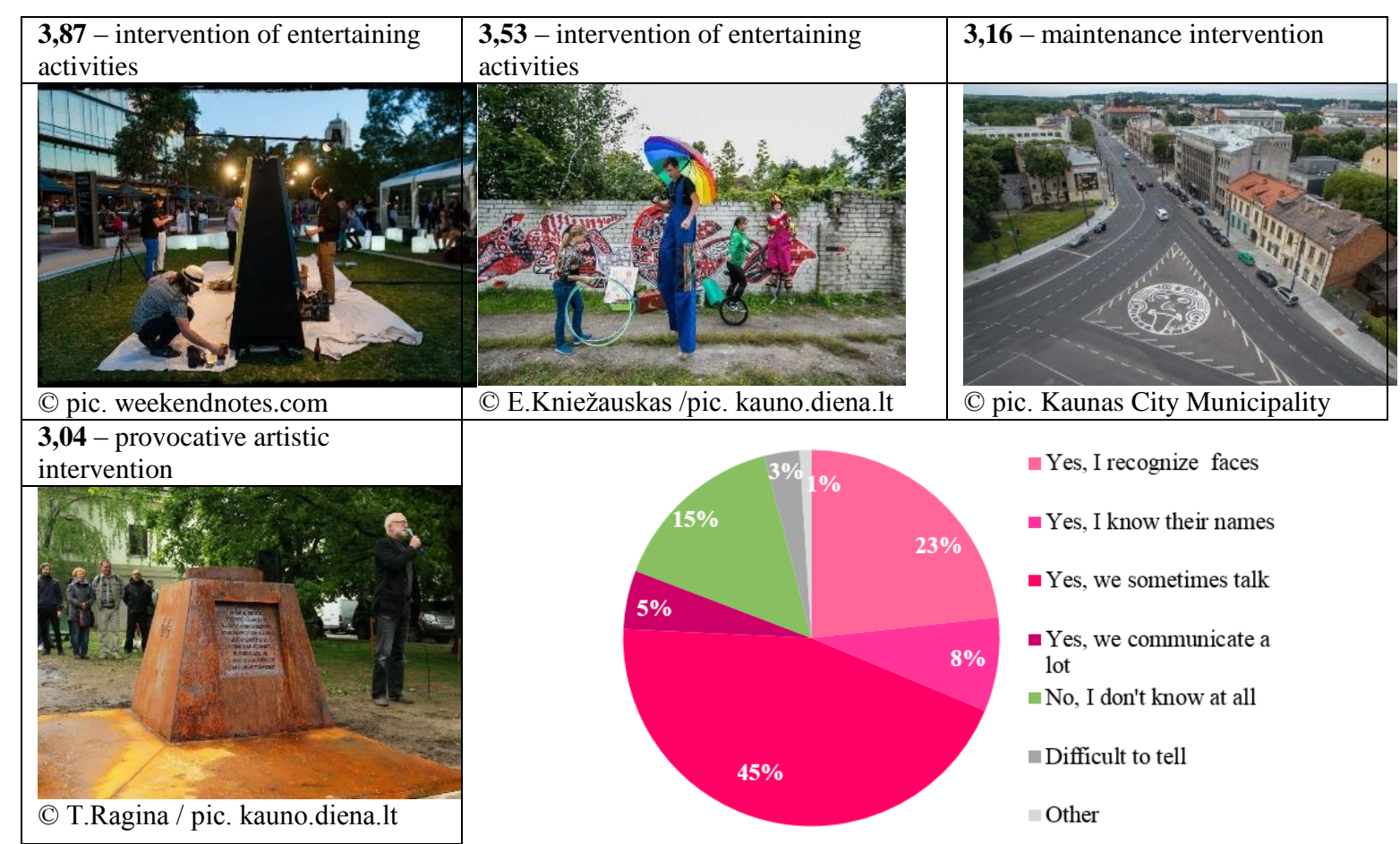

Fig. 4. Question: how well do you know your neighbors?

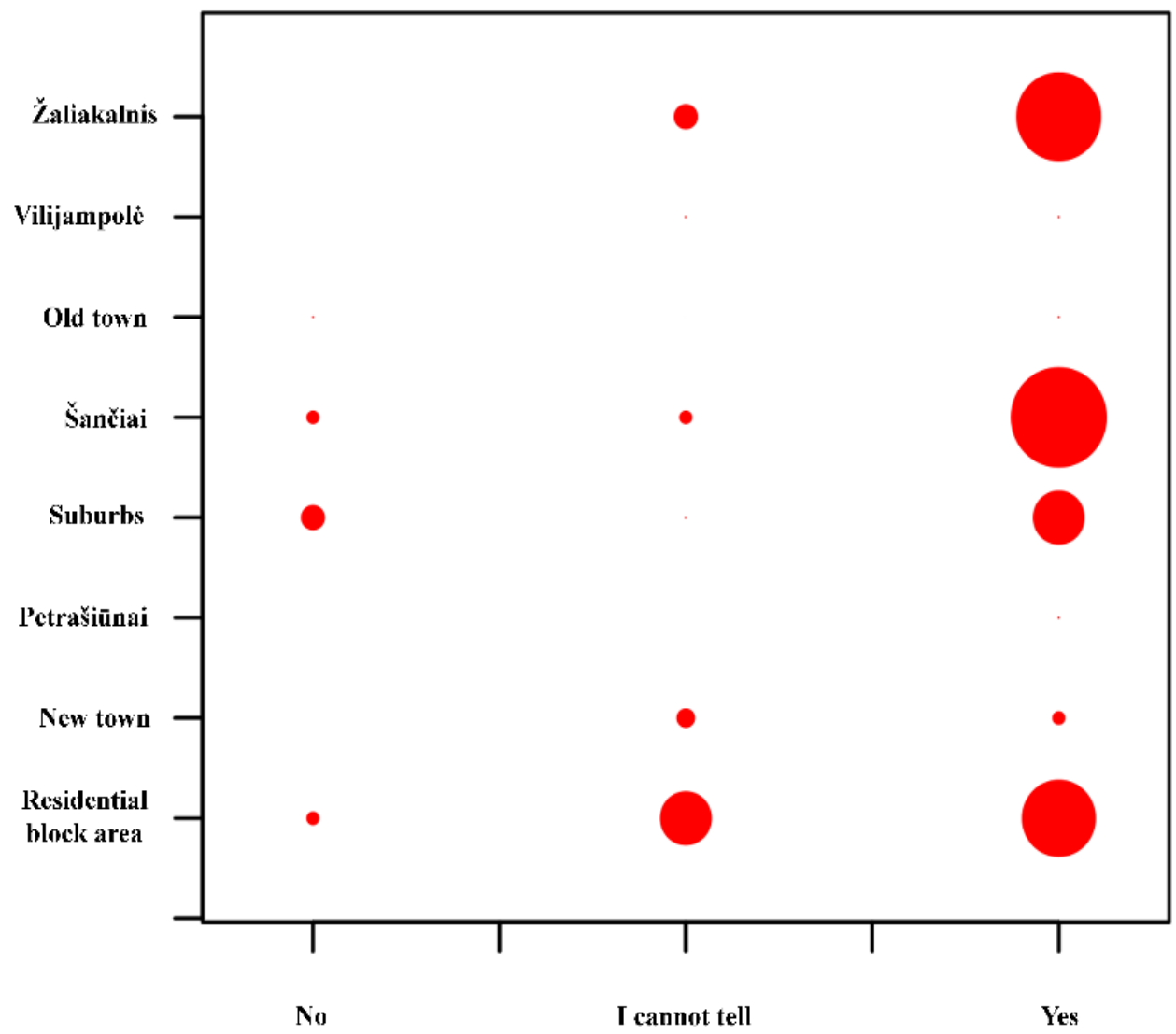

Fig. 5. Coherence between respondents' living area and their desire to be involved in the development of the surrounding environment. 


\section{Potential of involvement of residents in development of community spaces}

Urban acupuncture concept is based on the flows in the city and activities of people, where communities play an important role. Potential involvement of communities is one of the most important factors in urban acupuncture theory. Therefore, this study analyzed relation between communities and Kaunas' urban interventions.

In order to find out the possibilities of gathering communities through urban acupuncture interventions, current and possible relations among neighbors were analyzed as well as people's involvement in creating their surrounding environment.

The most of the respondents know their neighbors quite well, thus it is assumed that the urban intervention might encourage further communication (Fig. 4).

$64 \%$ of residents would like to participate in creating their surrounding environment and only

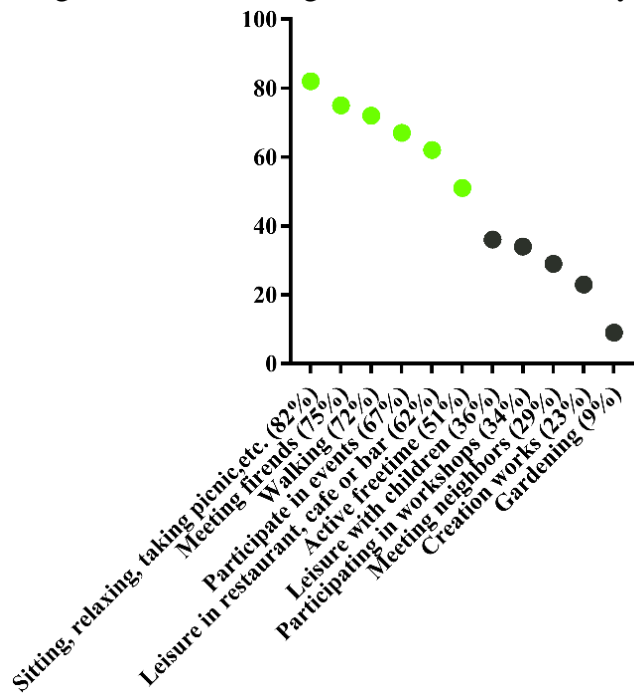

Fig. 6. Question: what would you like to do in city's public spaces.
$12 \%$ would not create their living environment. $73 \%$ of respondents told that they would sometimes visit the community space in their neighbourhood and $41 \%$ would help to create this kind of community space. Only $4 \%$ of respondents think that government should create community spaces for neighbourhood. Therefore, it is expected that communities would be involved in creating urban acupuncture interventions.

This study also tried to find coherence between respondents' living area and their desire to be involved in forming the surrounding environment.

The statistical calculation showed that people desire to be involved in creation of their environment (Fig. 5).

\section{Attitudes towards functioning and aesthetics of urban public spaces}

Residents would go to visit even such neglected areas as Vilijampole is today, if they had interest there. $42 \%$ of residents answered 'yes' and $48 \%$ 'maybe' when asked if they go to spend their leisure in Vilijampolè.

In order to find out the aesthetics preferences, residents were given four different types of urban environment to choose their favourite one. Most of the residents (54\%) chose 'balanced urbanecological environment' as their preferred (Fig. 7).

\section{The need of public spaces}

$67 \%$ of respondents answered 'yes' to the question 'Is there a lack of public spaces in your neighborhood for spending your free time?'. People suggested the most needed spaces: café or other communal space for youth to spend their free time in winter; café for families with children; space for creativity; green spaces; multifunctional, cooperation spaces; areas for children and pets.

People remembered a lot of changes that catalyzed activities in previously abandoned spaces. Their memories can be grouped as seen in Table 4 .

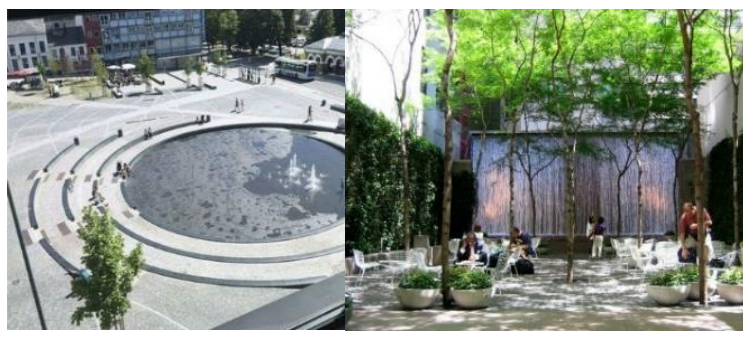

Very urbanized, hard surfaces are

predominant

(C) pic. pinterest.co.uk
Urbanized with natural elements

(C) pic. curbd.org
Balanced urban-ecological
environment
C pic. arch2o.com

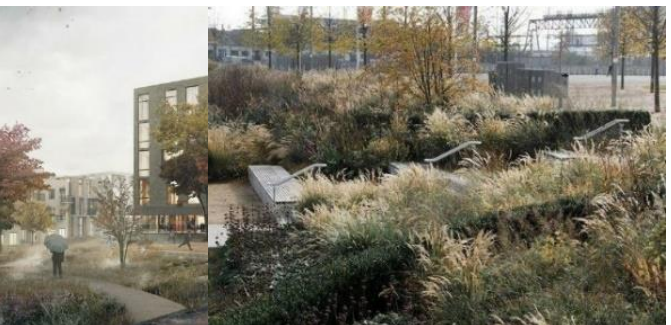

Highly ecological - wild plants are predominant

(C) pic. nigeldunnett.com

Fig. 7. Different types of urban environment. 
The groups of people's memories of changes in abandoned urban spaces that catalysed activities in the area.

\begin{tabular}{|l|l|}
\hline \multicolumn{1}{|c|}{ Changes } & \multicolumn{1}{|c|}{ No. of answers } \\
\hline The arrangement of the public space & 16 \\
\hline Food, entertainment, events, trips & 16 \\
\hline Maintenance projects of public green spaces & 15 \\
\hline Šančiai Cabbage Field & 8 \\
\hline Former 'Fluxus ministry' & 6 \\
\hline Activities of the communities & 4 \\
\hline Artists activities (interventions, initiatives) & 4 \\
\hline Conversion of abandoned buildings for permanent activities & 3 \\
\hline Total: & 72 \\
\hline
\end{tabular}

\section{Conclusions}

The results of the study shows potential possibilities of urban acupuncture interventions in Kaunas city. The majority of respondents (67\%) expressed the need of public spaces, which might be related more with quality of public spaces rather than physical space itself.

The reputation of the neighbourhood might be very important for the success of the urban acupuncture intervention. The results of the study showed that small scale interventions, which were implemented by communities or artists initiatives, were visited less in comparison with interventions, located in central part of the city and having better visual and physical connections with other spaces as well as having more activities around them.

Moreover, the majority of the respondents expressed their preference towards fully equipped, well maintained, multifunctional and offering a wide range of activities public spaces. During the study, trends of public space functions and aesthetics emerged. To the questions, concerning people leisure habits and preferences, desire to be in and visit natural areas as well as spaces for meeting and events were the strongest. Priorities of desired activities in the public spaces were set, which were recreation, socialization, walking, attending events and active leisure. Concerning aesthetics and identity of the space, balanced urban-natural environment was the most attractive for the people in their living environment.

In addition, people tend to move around the city in order to visit their favourite leisure places, which is probably because Kaunas is compact and small city, having well-functioning transport system.

It might be assumed that urban interventions can stimulate the formation of communities as well as the involvement of them into design and implementation of acupuncture interventions. The majority of the surveyed people know their neighbours quite well, people desire to participate in the development of their environment and to attend community spaces. Acupuncture intervention might be the gathering place in the life of community.

As urban-artistic phenomena and interventions of Kaunas city in general were evaluated well $(3,99$ points of 5,00$)$ by the respondents, it is assumed that such urban interventions are psychologically acceptable to the public and should be encouraged.

To sum up, the general recommendation for forming urban acupuncture interventions in Kaunas city would be to follow the functioning and aesthetics tendencies, described in this study, as well to improve existing public spaces of Kaunas with the help of community in the light of urban acupuncture concept.

\section{References}

1. Ellard, C. Psychogeography: Exploring the Brain's Reactions to Urban Design, 2015 [online 11.06.2018]. https://www.urbandesignmentalhealth.com/blog/category/urban-planning

2. Marciano, T. A. Applying Eastern Medicine Concepts in Urban Design for Mental Health 2016 [online 07.06.2018]. https://www.urbandesignmentalhealth.com/blog/category/urban-planning

3. Casagrande M. Urban Acupuncture [online 11.06.2018]. http://thirdgenerationcity.pbworks.com/f/urban\% 20acupuncture.pdf

4. Lerner, J. Urban Acupuncture. Celebrating Pinpricks of Change that Enrich City Life. London: Island Press, 2014, p. 230.

5. Iaconesi, S., Persico, O. Digital Urban Acupuncture. Human Ecosystems and the Life of Cities in the Age of Communication, Information and Knowledge. Springer, 2017. 239 p.

6. Tortosa, L., Vicent J. F., Zamora A., Oliver J. L. A Neural Network Model to Develop Urban Acupuncture. Lecture Notes in Computer Science, 2010, Vol. 6276, p. 31-40.

7. Khaerani, A. Introduction to Urban Acupuncture: Towards a Better Bandung City. [online]. Wordpress: What's the story? 2014 [cited 11.06.2018] https://khaeraniadenan.wordpress.com/2014/01/12/introduction-to-urbanacupuncture-towards-a-better-bandung-city/comment-page-1/

8. Network of Urban Acupuncture [online 11.06.2018]. http://www.urbanacupuncture.network/

9. Perez R. Social Acupuncture for Urban Growth 2017 [online 11.06.2018]. https://www.urban-future.org/singlepost/RebecaPerez 
10. Messeter, J. Social Media Use as Urban Acupuncture for Empowering Socially Challenged Communities. Journal of Urban Technology, 2015, Vol. 3(22), p. 79-96, DOI: 10.1080/10630732.2015.1040291

11. Melis, G., Gelormino, E., Marra, G., et al. The Effects of the Urban Built Environment on Mental Health: A Cohort Study in a Large Northern Italian City. International Journal of Environmental Research and Public Health, 2015, No.11(12), p. 14898-14915; doi:10.3390/ijerph121114898

12. Project for Public Spaces [online 11.06.2018]. https://www.pps.org/

13. Nassauer, J. I. Messy Ecosystems Orderly Frames. Landscape Journal, 1995, Vol. 2(14), p. 161-170.

14. Nassauer, J. I. The Appearance of Ecological Systems as a Matter of Policy. Landscape Ecology, 1992, Vol. 4(6), p. 239-250.

15. Gobster, P. H., Nassauer, J. I., Daniel, T. C., Fry, G. The Shared Landscape: What does Aesthetics have to do with Ecology? Landscape Ecology, 2007, Vol. 22, p. 959-972.

16. Deveikienè, V. Kraštovaizdžio architektūros ir urbanistikos sąveika - ar turime bendrą tikslą. Mokslas-Lietuvos ateitis, 2015, Vol. 1(7), p. 6-19.

17. Prapiestinè, R. Urbanizuotos aplinkos žaliųjų plotų sistemos erdvinės būklès ypatybès. Geografijos metraštis, 2003, Vol. 2(36), p. 115-123.

18. Kauno gatvès meno gidas [online 11.06.2018]. http://visit.kaunas.lt/lt/el-parduotuve/suvenyrai/knyga-kauno-gatvesmeno-gidas/

INFORMATION ABOUT THE AUTHORS:

Aurelija Daugèlaite - architect, master student at the Faculty of Civil Engineering of Kaunas University of Technology; Studentų 48, Kaunas, LT-51367, Lithuania; e-mail: aurelijai@gmail.com

Indrẻ Gražulevičiūtė-Vileniškè - PhD of Environmental Engineering and Land Management, Associated Professor at the Faculty of Civil Engineering of Kaunas University of Technology; Studentų 48, Kaunas, LT51367, Lithuania; e-mail: indre.grazuleviciute@ktu.lt

Mantas Landauskas - PhD of Informatics, lecturer at Faculty of Mathematics and Natural Sciences of Kaunas University of Technology; Studentų 50, Kaunas, Lithuania; e-mail: mantas.landauskas@ktu.lt

Kopsavilkums. Pēdējos gadu desmitos populārs ir kḷuvis urbānās akupunktūras koncepts, kas ir balstīts uz urbānās vides aktivizēšanu un revitalizāciju, izmantojot nelielu arhitektūras vai ainavu arhitektūras iejaukšanos noteiktās vietās urbānajā vidē. Tomēr urbānās akupunktūras netradicionālie dizaina risinājumi, kas pārsvarā balstîti uz ekoloǵisku dizainu, dabas ritumu, ielu mākslu un pārstrādājamiem materiāliem, var izsaukt dažādas reakcijas. Lai veiksmīgi integrētu urbānās akupunktūras projektus Lietuvas pilsētās ir svarīgi apkopot iedzīvotāju viedokḷus par publisko telpu izmantošanu, estētiku un mākslu. Pētījuma mērķis ir analizēt Kauṇas pilsētas iedzīvotāju viedokḷus šajos jautājumos. Lai sasniegtu mērḳi, tika veikta socioloǵiskā aptauja. Aptauja sastāvēja no 20 jautājumiem un tika veidota ar mērķi noteikt publiskās telpas izmantošanas tendences pilsētā un iedzīvotāju attieksmi pret dažāāām maza apjoma iniciatīvām, kas tikušas realizētas pēdējos gados Šajā tiešsaistes aptaujā piedalījās 100 Kauņas pilsētas iedzīvotāji un tās rezultāti uzrāda pozitīvu attieksmi pret mūsdienu publiskās vides dizaina tendencēm un publisko mākslu, tomēr aptaujātie iedzīvotāji deva priekšroku pilnībā aprīkotai publiskajai viei, kurā tiek piedāvātas dažāda veida aktivitātes. 